\title{
Adhesive Strength of Pilot-Scale-Produced Water-Washed Cottonseed Meal in Comparison with a Synthetic Glue for Non-Structural Interior Application
}

\author{
Zhongqi He ${ }^{1} \&$ Fabio Chiozza ${ }^{2}$ \\ ${ }^{1}$ Southern Regional Research Center, USDA Agricultural Research Service, New Orleans, LA 70124, USA \\ ${ }^{2}$ Vinavil SpA-R\&D, Villadossola, Italy \\ Correspondence: Zhongqi He, USDA-ARS, 1100 Robert E. Lee Blvd., New Orleans, LA 70124, USA. Tel: 1-(504) \\ 286-4516. Fax: 1-(504) 286-4367. E-mail: Zhongqi.He@ars.usda.gov
}

Received: June 2, 2017

Accepted: June 14, 2017

Online Published: June 21, 2017

doi:10.5539/jmsr.v6n3p20

URL: https://doi.org/10.5539/jmsr.v6n3p20

\begin{abstract}
Water-washed cottonseed meal (WCSM) has been shown the potential to be used as renewable and environmentfriendly adhesives in wood products industry. Recently, WCSM was produced from defatted meal in a pilot scale. In this study, we initially compare the adhesive strength of the pilot-produced WCSM with that of a synthetic glue Vinavil 2259 L. WCSM may be used as the conventional D1 wood adhesives for nonstructural interior application per European standard EN204/205. Non-structural D3 type adhesives is more widely used in protected outside. Under the testing conditions, WCSM possessed very high heat resistance according to European standard EN14257 (WATT 91)-adhesive strength after 1 hour at $80^{\circ} \mathrm{C}$. However, the dry strength (EN204/205) and water resistance (specimen were put in water for 4 days and then pulled in the dynamometer) of WCSM were lower than those of the synthetic glue Vinavil 2259 L. Blending WCSM with Vinavil 2259 L improved the water resistance of WCSM, allowing the classification of the WCSM adhesive as D3. Further work will be focused on the increase of solid content of the final adhesive slurries and the improvement of their water resistance.
\end{abstract}

Keywords: cottonseed, washed cottonseed meal, wood adhesive, poly(vinyl acetate), water resistance, heat resistance

\section{Introduction}

Adhesive bonding is a key factor for efficiently utilizing timber and other lignocellulosic resources. The types of adhesives commonly used in the wood industry for furniture applications can be both thermosetting and thermoplastic in nature. The choice of a specific adhesive for use depends on several criteria in application, such as final use, required performances, costs, application process, and environmental issues. Among the thermoplastic polymers, water-based poly(vinyl acetate) (PVAc) dispersions are the most used as the basis for glues to be used with wood and wood products (Chiozza \& Pizzo, 2016, 2013a, 2013b).

On the other hand, as synthetic glues are mostly derived from depleting petrochemical resource and have caused increasing environmental concern, natural product and byproduct derived adhesives have attracted much attention in the last couple of decades (He, 2017; Pizzi and Mittal, 2011). Whereas soy protein has been extensively studied for this purpose (Chen et al., 2014; Luo et al., 2015; Qi et al., 2017), other vegetable proteins can also serve as wood adhesives (He \& Wan, 2017; Santoni \& Pizzo, 2013). Vegetable proteins are typically isolated from the seed meals by base extraction and acid precipitation. To reduce the cost, researchers have also tried to directly use the seed meals as wood adhesives (He et al., 2016b; Lorenz et al., 2015; Luo et al., 2016; Shi et al., 2017). In recent years, He and his colleagues have demonstrated that water-washed cottonseed meal (WCSM) could serve as promising wood adhesives (He et al., 2014a, 2014b, 2014c). Indeed, WCSM showed the adhesive performance comparable to cottonseed protein isolate (He et al., 2016c, 2016d). Recently, the product WCSM was produced in a pilot scale, yielded adequate amounts for practical application evaluation per industrial standards (He \& Cheng, 2017b; He et al., 2016e). Thus, to promote WCSM as an industrial wood adhesive for non-structural application, in this work, we tested the WCSM's adhesive performance in reference to the relevant European industrial standards. The results were further compared with an industrial synthetic glue Vinavil $2259 \mathrm{~L}$. The information presented in this work would be helpful in formulating industrially applicable WCSM-based wood adhesives. 


\section{Methods}

\subsection{Materials}

WCSM was prepared from mill-produced cottonseed meal in a pilot scale (He et al., 2016e), and its basic properties were listed in Table 1. Beech (Fagus sylvatica L.) with a density of $695 \pm 15 \mathrm{~kg} \mathrm{~m}^{-3}$ and regular grain as specified in EN 205 (2016) was used for the preparation of the various specimens. Wood assemblies were prepared by gluing beech thin boards of $640 \mathrm{~mm} \times 125 \mathrm{~mm}$ x $5 \mathrm{~mm}$. Each thin board was divided in two parts and, after spreading the adhesive on both sides, they were overlapped and put under the press to prepare the assembly (Chiozza \& Pizzo, 2016).

Table 1. Selected components of pilot-produced washed cottonseed meal (WCSM). ADL- acid detergent lignin.

\begin{tabular}{llllllll}
\hline Major component & Moisture & Protein & Oil & Crude Fiber & ADL & Cellulose & Hemicellulose \\
\hline$\%$ & 8.6 & 46.3 & 1.0 & 16.0 & 9.4 & 17.6 & 8.4 \\
Macro mineral & Ash & $\mathrm{P}$ & $\mathrm{Ca}$ & $\mathrm{K}$ & $\mathrm{Mg}$ & $\mathrm{Na}$ & $\mathrm{S}$ \\
$\%$ & 5.2 & 1.22 & 0.27 & 1.04 & 0.67 & 0.08 & 0.46 \\
Trace mineral & $\mathrm{Fe}$ & $\mathrm{Zn}$ & $\mathrm{Cu}$ & $\mathrm{Mn}$ & $\mathrm{Ni}$ & $\mathrm{Al}$ & $\mathrm{B}$ \\
$\mathrm{mg} \mathrm{kg}^{-1}$ & 166 & 100 & 15 & 50 & 0.5 & 130 & 20 \\
\hline
\end{tabular}

\subsection{Wood Bonding}

Pilot-produced WCSM was used as it was without further treatments. WSCM was first mixed with water (11\% of solid content). WSCM slurry was applied for the bonding in the rates of $150 \mathrm{~g} \mathrm{~m}^{-2}$ and $250 \mathrm{~g} \mathrm{~m}^{-2}$, respectively (wet weight). Wood assemblies were prepared by gluing beech thin boards of $640 \mathrm{~mm}$ x $125 \mathrm{~mm} \times 5 \mathrm{~mm}$. Each thin board was divided in two parts and, after spreading the adhesive on both sides, they were overlapped and put under the press $\left(8 \mathrm{~kg} \mathrm{~cm}^{-2}\right.$ or $\left.0.8 \mathrm{MPa}\right)$ for $30 \mathrm{~min}$ at $130^{\circ} \mathrm{C}$ to prepare the assembly (open time less than 1 minute, closed time 4 minutes, pressing time 3 min, adhesive quantity $150 \mathrm{~g} \mathrm{~m}^{-2}$ by spreading the glue on each side of the assembly) unless specified otherwise (Chiozza and Pizzo, 2016).

For comparison, the synthetic glue, Vinavil $2259 \mathrm{~L}$, was used in bonding beech boards under the same conditions. Vinavil $2259 \mathrm{~L}$ is water based PVAc dispersion adhesive with the characteristics reported in Table 2. It is a water resistant adhesive belonging to the D3 class as defined by EN 204 (2016).

Table 2.Typical analytical and technical characteristics of Vinavil 2259 L

\begin{tabular}{lll}
\hline Analytical Characteristics & Method & Value \\
\hline Polymer base & - & PVAc \\
Dispersing system & - & PVOH \\
Solid content & ISO 3251:2005 & $48 \pm 1 \%$ \\
Viscosity & ISO 2555:2002 & $11,500 \pm 2,500 \mathrm{mPa} \cdot \mathrm{s}$ \\
$\mathrm{pH}$ & ISO 976:1996 & $4.5 \pm 0.5$ \\
Minimum film forming temperature & ISO 2115:1996 & $+3^{\circ} \mathrm{C}$ \\
\hline Durability class & EN 204:2016 & D3 \\
\hline
\end{tabular}

\subsection{Adhesive Strength Testing}

Mechanical tests were carried out to evaluate the performances of bonded specimens. The glued specimens were conditioned for 7 days in standard climate $\left(23{ }^{\circ} \mathrm{C}\right.$ and $50 \%$ relative humidity) before measuring dry shear strength values. Further treatments of water soaking or heat exposure were conducted for those specimens used for water and heat resistance evaluation. Specifically, wet shear strengths were evaluated immediately after further complete immersion of specimens in water for 4 days at $23{ }^{\circ} \mathrm{C}$ per EN 204 (2016) values. Heat resistance was evaluated after exposing samples to the temperature of $80^{\circ} \mathrm{C}$ for $1 \mathrm{~h}$ in an oven with well circulated air per EN14257 (2006). Tests were carried out on a universal test machine MTS Alliance RT/50, load cell $50 \mathrm{kN}$, class $0.5 \%$ according to ISO7500/1. Ten specimens $(20 \mathrm{~mm} \times 150 \mathrm{~mm}$, length of tested surface $10 \mathrm{~mm})$ from same assembly were used for each type of testing and the average values without the SD values were reported in order to show a clear cutoff on if the strength values meet the criteria of a specific durability class or not (Chiozza et al., 2013a, 2013b). 


\section{Results and Discussion}

\subsection{Adhesive Performance of WCSM}

The results of the WCSM adhesive performance are listed in Table 3. The dry shear strength of WCSM was 10.7 and $9.3 \mathrm{MPa}$, respectively, with the application rated of $150 \mathrm{~g} \mathrm{~m}^{-2}$ (WCSM 1) and $250 \mathrm{~g} \mathrm{~m}^{-2}$ (WCSM 2). The application rate seemed not to be a factor to influence the adhesive performance of WCSM as the two sets of data with different WSCM application rates were basically same. Previously, Cheng et al. ( 2013) reported that there was no difference in the adhesive strength of both cottonseed and soy protein-based adhesives when the adhesive slurries were applied onto the maple veneers once, twice, or three time (i. e., 1-, 2-, or 3-layers of adhesives). Similarly, He \& Cheng (2017a) found that the impact of varying solid content between $11 \%$ and $30 \%$ of WCSM on its adhesive strength was not obvious with press temperature at $100{ }^{\circ} \mathrm{C}$. Our observation in this work was consistent with the early observations. On the other hand, the dry adhesive strength of WCSM observed in this work was much higher than the literature data (around 3.3 to 5.6 MPa) (He et al., 2016d). The higher adhesive strength observed in this work was apparently due to the thicker wood specimens and different bonding/testing conditions.

Table 3. Adhesive strength of WCSM adhesives with the application rated of $150 \mathrm{~g} \mathrm{~m}^{-2}$ (WCSM 1) and $250 \mathrm{~g} \mathrm{~m}^{-2}$ (WCSM 2). Bonding conditions: $30 \mathrm{~min}$ and $130^{\circ} \mathrm{C}$

\begin{tabular}{llccc}
\hline \multirow{2}{*}{ Testing type } & Testing conditions & \multirow{2}{*}{ Method applied } & \multicolumn{2}{c}{ Adhesive strength (MPa) } \\
\cline { 4 - 5 } & & WCSM 1 & WCSM 2 \\
\hline Durability class D1 & Dry adhesive strength & EN 204/205 & 10.7 & 9.3 \\
Durability class D2 & 3-h soaking and re-conditioning for 7 days & EN204/205 & 1.2 & $-{ }^{\text {a }}$ \\
Durability class D3 & Strength after water soaking for 4 days & EN204/205 & 0.5 & 0.3 \\
Heat resistance & Adhesive strength after 1 hour at $80^{\circ} \mathrm{C}$ & EN14257 & 8.9 & 9.1 \\
\hline
\end{tabular}

${ }^{\mathrm{a}}$ No test.

Soaking and drying decreased the adhesive strength (soaked strength) of the glue with the application rate of $150 \mathrm{~g}$ $\mathrm{m}^{-2}$ to $1.2 \mathrm{MPa}$. After soaking for 4 days, the adhesive strength decreased to 0.5 and $0.3 \mathrm{MPa}$, respectively, for the adhesives with the application rate of $150 \mathrm{~g} \mathrm{~m}^{-2}$. The decreasing trend of adhesive strength by water soaking was observed before, however, the extent of the decrease observed in this study was greater than the water decrease reported in the literature (He et al., 2016c, 2016d). The previous studies have shown that water soaking - re-drying cycles decreased much less, in some case even increased a little bit, the adhesive strength of WCSM or cottonseed protein adhesives (Cheng et al., 2016; He et al., 2016c). The difference in bonding and testing procedure is a possible affecting factor on the different observations. We also noticed some differences in the pilot-scale produced WCSM and the laboratory-produced product, such as a higher fiber content in cottonseed meal used in the pilot-scale production (He et al., 2016e, 2015) and no further grinding of the pilot product. It is worth while further exploring the effect of these parameters on the water resistance data. The adhesive strength after the bonded specimens exposed for 1 hour at $80^{\circ} \mathrm{C}$ was around $9.0 \mathrm{MPa}$, just about $10 \%$ decrease in average, compared to the dry adhesive strength. These data indicated that WSCM-based adhesives possessed good heat resistance. No heat resistance data of WCSM was reported before.

Table 4. Effect of bonding temperature on adhesive strength of WCSM adhesives. Bonding conditions: application rate- $150 \mathrm{~g} \mathrm{~m}^{-2}$, press pressure- $0.8 \mathrm{MPa}$, and press time- $30 \mathrm{~min}$

\begin{tabular}{llll}
\hline Testing type & $23{ }^{\circ} \mathrm{C}$ & $130{ }^{\circ} \mathrm{C}$ & $250{ }^{\circ} \mathrm{C}$ \\
\hline Solid content (\%) & 11 & 11 & 11 \\
Dry strength (MPa) & Not tested ${ }^{\text {a }}$ & 10.7 & 9.9 \\
Water resistance (MPa) & Not tested & 0.5 & 0.3 \\
Hot resistance (MPa) & Not tested & 8.9 & 9.1 \\
\hline
\end{tabular}

${ }^{\text {a }}$ Breaking during gluing operations (i.e., the joints were opening after pressing).

\subsection{Effect of Bonding Temperature}

The bonding performance of WCSM was further tested at different temperatures (Table 4). Application of WCSM to bond the wood panels assembled at room temperature $\left(23^{\circ} \mathrm{C}\right)$ was failed. This was not surprising as such results 
were observed previously with protein-based wood adhesives (Kalapathy et al., 1995). Chemical reagents which denature protein's native structures could be used to improve the bonding ability at low temperatures whereas hot pressing is more effective way for higher bonding strength of the protein-based wood adhesives (Kalapathy et al., 1995; Zhong \& Sun, 2001). It is reported that the adhesive strength of WCSM increased dramatically from press temperature at $40,60,80^{\circ} \mathrm{C}$ to $100{ }^{\circ} \mathrm{C}$ (He et al., 2016a, 2014a), and did not increased more between 110 and 130 ${ }^{\circ} \mathrm{C}$ of the tested range. In this work, the highest press temperature was set at $250 \mathrm{oC}$. Data in Table 4 suggested no substantial difference in the adhesive strength for all three tested conditions between 130 and $250{ }^{\circ} \mathrm{C}$. This observation was consistent with the maximal strength of WCSM at $110-130{ }^{\circ} \mathrm{C}$, but different from the soy meal -based adhesives (Frihart et al., 2016). Especially, wet strength of soy-meal based adhesive greatly increased when the bonding temperature was increased from $120^{\circ} \mathrm{C}$ to 150 and $180{ }^{\circ} \mathrm{C}$ (Frihart et al., 2016). Thus, a high press temperature [e. g., $180^{\circ} \mathrm{C}$ (Wang et al., 2009)] is justified for the soy protein adhesives, but $110-130{ }^{\circ} \mathrm{C}$ should be recommended for cotton meal based adhesives for energy savings.

Table 5. Four types of wood adhesives for non-structural applications and their classification requirements per European Standards (EN204, 2016; EN205, 2016; EN14257, 2006). NR=not required.

\begin{tabular}{lllllll}
\hline \multirow{2}{*}{ Adhesive type } & \multirow{2}{*}{ Application field condition } & \multicolumn{5}{c}{ Minimum mean tensile shear strength of 10 testing (MPa) } \\
\cline { 3 - 6 } & & $\mathrm{T} 1$ & $\mathrm{~T} 2$ & $\mathrm{~T} 3$ & $\mathrm{~T} 4$ & $\mathrm{~T} 5$ \\
\hline D1 & Inside & 10 & $\mathrm{NR}$ & $\mathrm{NR}$ & $\mathrm{NR}$ & $\mathrm{NR}$ \\
$\mathrm{D} 2$ & Inside, rare contact with water & 10 & 8 & $\mathrm{NR}$ & $\mathrm{NR}$ & $\mathrm{NR}$ \\
$\mathrm{D} 3$ & Protected outside & 10 & $\mathrm{NR}$ & 2 & 8 & $\mathrm{NR}$ \\
D4 & Outside, exposed to the weather with protection & 10 & $\mathrm{NR}$ & 4 & $\mathrm{NR}$ & 4 \\
\hline
\end{tabular}

T1: Test immediately after 7 days in standard atmosphere at $20^{\circ} \mathrm{C}$ and $65 \%$ relative humidity.

T2: 7-day conditioning as T1, 3-h soaking in water at $20 \pm 5{ }^{\circ} \mathrm{C}$, samples tested in the dry state after re-conditioning for 7 days.

T3: 7-day conditioning as $\mathrm{T} 1$, 4-day soaking in water at $20 \pm 5^{\circ} \mathrm{C}$, samples tested immediately in the wet state.

T4: 7-day conditioning as T1, 4-day soaking in water at $20 \pm 5{ }^{\circ} \mathrm{C}$, samples tested in the dry state after re-conditioning for 7 days.

T5: 7-day conditioning as T1, 3-h soaking in boiling water, 2-h soaking in water at $20 \pm 5{ }^{\circ} \mathrm{C}$, samples tested immediately in the wet state.

Table 6. Effect of solid content and WCSM addition on the adhesive strength of Vinavil $2259 \mathrm{~L}$ measured with the same testing conditions in Table 3

\begin{tabular}{lllll}
\hline & & $100 \mathrm{pbw}$ Vinavil + & $100 \mathrm{pbw}$ Vinavil + & \\
Testing type & Testing conditions & $10 \mathrm{pbw}$ water & $10 \mathrm{pbw}$ WCSM & Vinavil as it is \\
\hline Solid content (\%) & $110^{\circ} \mathrm{C}$ for 30 min & 44.4 & 44.8 & 48.0 \\
Durability class D1 (MPa) & Dry strength & 15.5 & 12.3 & 15.8 \\
Durability class D2 (MPa) & Soaked strength & 11.4 & 9.5 & 10.8 \\
Durability class D3 (MPa) & Water resistance & 3.5 & 3.8 & 4.8 \\
Heat resistance (MPa) & Heat resistance & 5.5 & 6.0 & 7.0 \\
\hline
\end{tabular}

pbw =parts by weight.

European standards classify wood adhesives for non-structural application into four types (Table 5). EN204 (2016) requires a minimum average strength of $10 \mathrm{MPa}$ for class D1 wood adhesives. The WCSM slurry prepared under the experimental conditions marginally meets the requirement. For more widely used D3 adhesives, a minimum average strength of $2 \mathrm{MPa}$ of water resistance is needed. The wet strength of the WCSM slurries was between 0.3-0.5 MPa. The heat resistance value (former WATT91 value) of WCSM was around 9.0. For practical applications, a minimum value of $7 \mathrm{MPa}$ is usually considered an acceptable value for a D3 wood adhesive (EN14257, 2006). Thus, the WCSM data meet the heat resistance requirement of D3 adhesives, but the wet resistance of WCSM needs significant improvements as D3 adhesives. Addition of some chemicals, such as $\mathrm{AlCl}_{3}$ (Chiozza et al., 2013b), and anionic organic compounds (Cheng et al., 2016), will be tested in the future for this purpose. 


\subsection{Blending WCSM with Vinavil 2259 L}

The results of the adhesive performance of the comparative synthetic glue Vinavil $2259 \mathrm{~L}$ are listed in Table 6. The solid content of the three formulations of the adhesives was all $>44.0 \%$. Compared to the WCSM-based adhesives, the synthetic glue showed better water resistance, but poorer heat resistance.

Blending natural products with synthetic resins is a short-term solution for reducing dependence on petrochemicals and lowering emissions of volatile organic compounds (Qi \& Sun, 2011). Thus, we tested the bonding performance of the blend of WCSM and Vinavil $2259 \mathrm{~L}$. With the hot press temperature at $130{ }^{\circ} \mathrm{C}$, the blend of WCSM and Vinavil 2259 L showed similar adhesive performance as the Vinavil $2259 \mathrm{~L}$ and its water diluted solution (Table 6). With the cold $\left(23^{\circ} \mathrm{C}\right)$ pressing, unlike the pure WCSM adhesives with failed bonding, the blend did not show negative impacts on the adhesive performance of Vianvil 2259 L (Figure 1). Whereas blending did not improve the heat resistance of the synthetic polymer by keeping the D3 class to the adhesive, it may be said that the addition of Vinavil $2259 \mathrm{~L}$ improved the water resistance of the WCSM allowing the classification of the adhesive as D3. It is reported that cellulose in nano crystalline forms could improve the mechanical properties of PVAc adhesives (Chaabouni \& Boufi, 2017; Kaboorani et al., 2012). The cellulose component in WCSM may also work in the same way while the particle size of WCSM could be a factor to affect the function. Future research on the blend of Vinavil $2259 \mathrm{~L}$ and WCSM with different blending ratios and particle sizes could shed light on the concern.

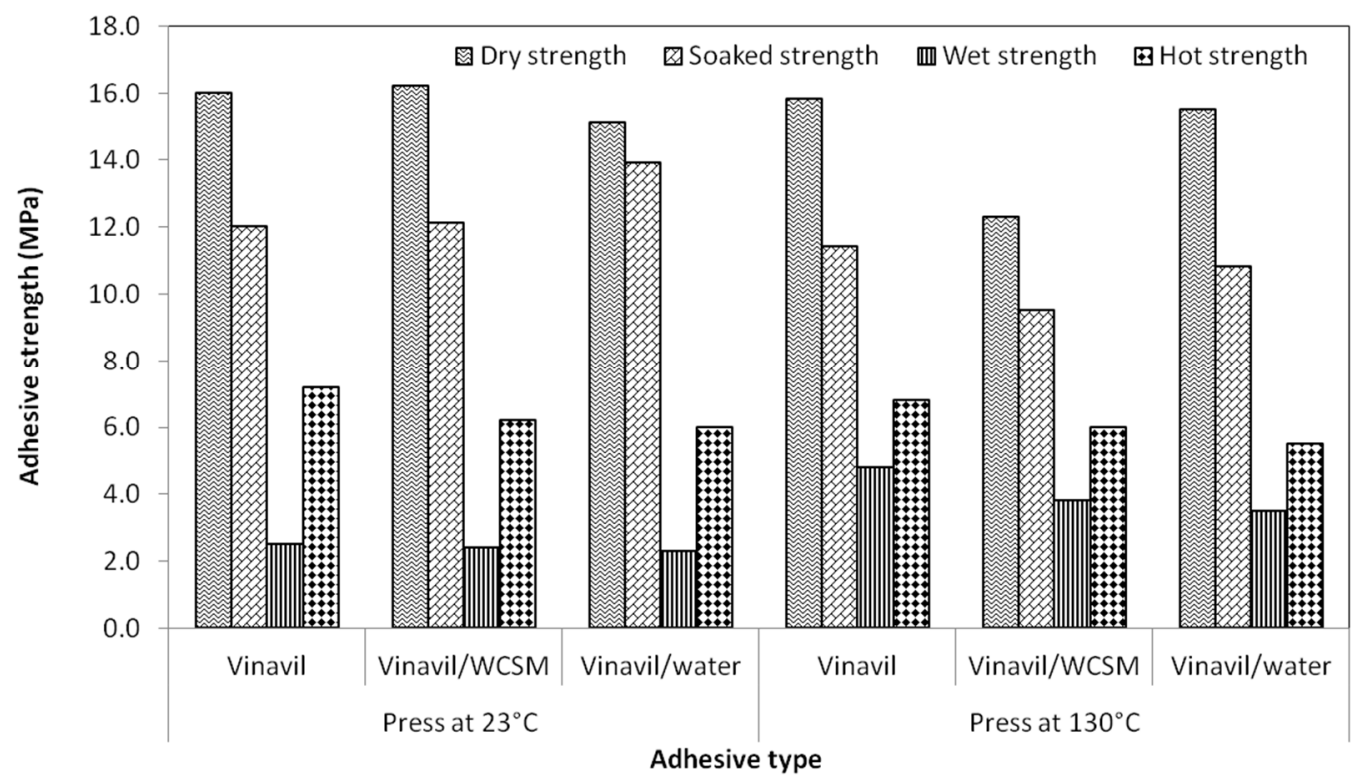

Figure 1. Effect of press temperature on the adhesive strength of synthetic glue Vinavil 2259 L (Vinavil ) and its blends with WCSM (Vinavil/WCSM) and water (Vinavil/water) in the ratio of 100:10

\section{Conclusion}

This study demonstrated that WCSM may be used as the conventional D1 wood adhesives for nonstructural interior application. There was no difference in the bonding performance between the hot press temperatures at 130 and $250^{\circ} \mathrm{C}$. Non-structural D3 type adhesives is more widely used in protected outside. WCSM also met the requirements of D3 with the dry adhesives strength and heat resistance. However, WCSM showed under-criteria value of water resistance. Future work will be on improvement of WSCM adhesive performance for D3 classification. The addition of $2259 \mathrm{~L}$ increased the performances of WCSM by allowing to reach a D3 glue, mainly after curing at $23-130^{\circ} \mathrm{C}$. The effects of blending with other synthetic adhesives, addition of $\mathrm{AlCl}_{3}$ and/or other ingredient, and lowering WCSM's particle size, will be tested in the future work. 


\section{Acknowledgments}

Mention of trade names or commercial products in this publication is solely for the purpose of providing specific information and does not imply recommendation or endorsement by the U.S. Department of Agriculture. USDA is an equal opportunity provider and employer.

\section{References}

Chaabouni, O., \& Boufi, S. (2017). Cellulose nanofibrils/polyvinyl acetate nanocomposite adhesives with improved mechanical properties. Carbohydr. Polym., 156, 64-70. https://doi.org/10.1016/j.carbpol.2016. 09.016 .

Chen, M., Chen, Y., Zhou, X., Lu, B., He, M., Sun, S., \& Ling, X. (2014). Improving water resistance of soy-protein wood adhesive by using hydrophilic additives. BioResources, 10, 41-54.

Cheng, H.N., Dowd, M.K., \& He, Z. (2013). Investigation of modified cottonseed protein adhesives for wood composites. Ind. Crop. Prod., 46, 399-403. https://doi.org/10.1016/j.indcrop.2013.02.021

Cheng, H. N., Ford, C. V. Dowd, M. K., \& He, Z. (2016). Use of additives to enhance the properties of cottonseed protein as wood adhesives. Int. J. Adhes. Adhes., 68, 156-160. https://doi.org/10.1016/j.ijadhadh.2016. 02.012

Chiozza, F., \& Pizzo, B. (2016). Innovation in poly(vinyl acetate) water resistant D3 glues used in wood industry. Int. J. Adhes. Adhes., 70, 102-109. http://dx.doi.org/10.1016/j.ijadhadh.2016.06.003

Chiozza, F., Santoni, I., Toniolo, F., \& Pizzo, B. (2013a). Investigation on the bonding disoloration of PVAc in wood assemblies. In Proceedings of the 4th International Scientific Conference on Hardwood Processing (pp. 241-249). CNR-IVALSA, Florence, Italy.

Chiozza, F., Toniolo, F., \& Pizzo, B. (2013b). Effects of radio frequency and heat on wood bonding with a poly (vinyl acetate) dispersion adhesive. J. Appl. Polymer Sci., 129, 1157-1169. https://doi.org/10.1002/app. 38805.

EN204. (2016). Classification of thermoplastic wood adhesives for non-structural applications. Brussels:European Committee for Standardization CEN.

EN205. (2016). Adhesives. Wood adhesives for non-structural applications. Determination of tensile shear strength of lap joints. Brussels: European Committee for Standardization CEN.

EN14257. (2006). Adhesives - Wood adhesives - Determination of tensile strength of lap joints at elevated temperature (WATT '91). Brussels: European Committee for Standardization CEN.

Frihart, C., Coolidge, T., Mock, C., \& Valle, E. (2016). High bonding temperatures greatly improve soy adhesive wet strength. Polymers, 8, 394. https://doi.org/310.3390/polym8110394.

He, Z. (ed.). (2017). Bio-based Wood Adhesives: Preparation, Characterization, and Testing. CRC Press, Boca Raton, FL.

He, Z., Chapital, D.C., \& Cheng, H.N. (2016a). Adhesive performance of washed cottonseed meal at high solid contents and low temperatures. Proceedings of the 70th Forest Products Society (FPS) international Convention, June 27-29, 2016, Portland, OR.

He, Z., Chapital, D.C., \& Cheng, H.N. (2016b). Comparison of the adhesive performances of soy meal, water washed meal fractions, and protein isolates. Modern Appl. Sci., 10(5), 112-120. http://dx.doi.org/10.5539/ mas.v10n5p112.

He, Z., Chapital, D.C., \& Cheng, H.N. (2016c). Effects of pH and storage time on the adhesive and rheological properties of cottonseed meal-based products. J. Appl. Polymer Sci., 133, 43637. https://doi.org/43610. 41002/APP.43637.

He, Z., Chapital, D.C., Cheng, H.N., \& Dowd, M.K. (2014a). Comparison of adhesive properties of water- and phosphate buffer-washed cottonseed meals with cottonseed protein isolate on maple and poplar veneers. Int. J. Adhes. Adhes., 50, 102-106. https://doi.org/10.1016/j.ijadhadh.2014.01.019

He, Z., Chapital, D.C., Cheng, H.N., Klasson, K.T., Olanya, M.O., \& Uknalis, J. (2014b). Application of tung oil to improve adhesion strength and water resistance of cottonseed meal and protein adhesives on maple veneer. Ind. Crop. Prod., 61, 398-402. https://doi.org/10.1016/j.indcrop.2014.07.031.

He, Z., Chapital, D.C., Cheng, H.N., \& Olanya, O.M. (2016d). Adhesive properties of water-washed cottonseed meal on four types of wood. J. Adhes. Sci. Technol., 30, 2109-2119. https://doi.org/10.1080/01694243.2016. 1175245. 
He, Z., \& Cheng, H.N. (2017a). Evaluation of wood bonding performance of water-washed cottonseed meal-based adhesives with high solid contents and low press temperatures. J. Adhes. Sci. Technol. https://doi.org/10.1080/01694243.01692017.01313184.

He, Z., \& Cheng, H.N. (2017b). Preparation and utilization of water washed cottonseed meal as wood adhesives. In He, Z. (ed.), Bio-based Wood Adhesives: Preparation, Characterization, and Testing (pp. 156-178). CRC Press, Boca Raton, FL.

He, Z., Cheng, H.N., Chapital, D.C., \& Dowd, M.K. (2014c). Sequential fractionation of cottonseed meal to improve its wood adhesive properties. J. Am. Oil Chem. Soc., 91, 151-158. https://doi.org/10.1007/s11746-01 3-2349-2.

He, Z., Klasson, K.T., Wang, D., Li, N., Zhang, H., Zhang, D., \& Wedegaertner, T.C. (2016e). Pilot-scale production of washed cottonseed meal and co-products. Modern Appl. Sci., 10 (2), 25-33. http://dx.doi.org/10.5539/mas.v10n2p25.

He, Z., \& Wan, H. (2017). Bio-based wood adhesives research: advances and outlooks. In He, Z. (ed.), Bio-based Wood Adhesives: Preparation, Characterization, and Testing (pp. 340-353). CRC Press, Boca Raton, FL.

He, Z., Zhang, H., \& Olk, D.C. (2015). Chemical composition of defatted cottonseed and soy meal products. PLoS One, 10(6), e0129933. https://doi.org/0129910.0121371/journal.pone.0129933

Kaboorani, A., Riedl, B., Blanchet, P., Fellin, M., \& Hosseinaei, O. (2012). Nanocrystalline cellulose (NCC): a renewable nano-material for polyvinyl acetate (PVA) adhesive. Eur. Polymer J., 48, 1829-1837.

Kalapathy, U., Hettiarachchy, N.S., Myers, D., \& Hanna, M.A. (1995). Modification of soy proteins and their adhesive properties on woods. J. Am. Oil Chem. Soc., 72, 507-510.

Lorenz, L., Birkeland, M., Daurio, C., \& Frihart, C. (2015). Soy flour adhesive strength compared to that of purified soy proteins. Forest Products J., 65, 26-30. https://doi.org/10.13073/FPJ-D-13-00020

Luo, J., Luo, J., Li, X., Li, K., Gao, Q., \& Li, J. (2016). Toughening improvement to a soybean meal-based bioadhesive using an interpenetrating acrylic emulsion network. J. Mater. Sci., 51, 9330-9341. http://dx.doi.org/10.1007/s10853-016-0180-5.

Luo, J., Luo, J., Yuan, C., Zhang, W., Li, J., Gao, Q., \& Chen, H. (2015). An eco-friendly wood adhesive from soy protein and lignin: performance properties. RSC Advances, 5, 100849-100855. https://doi.org/10.1039/ C5RA19232C

Pizzi, A., \& Mittal, K.L. (eds.). (2011). Wood adhesives. CRC Press, Boca Raton, FL.

Qi, G., Li, N., Sun, X.S., \& Wang, D. (2017). Adhesion properties of soy protein subunits and protein adhesive modification. In He, Z. (ed.), Bio-based Wood Adhesives: Preparation, Characterization, and Testing (pp. 59-85). CRC Press, Boca Raton, FL.

Qi, G., \& Sun, X.S. (2011). Soy protein adhesive blends with synthetic latex on wood veneer. J. Am. Oil Chem. Soc., 88, 271-281. https://doi.org/10.1007/s11746-010-1666-y

Santoni, I., \& Pizzo, B. (2013). Evaluation of alternative vegetable proteins as wood adhesives. Ind. Crop. Prod., 45, 148-154. http://dx.doi.org/10.1016/j.indcrop.2012.12.016.

Shi, S.Q., Xia, C., \& Cai, L. (2017). Modification of soy-based adhesives to enhance the bonding performance. In He, Z. (ed.), Bio-based Wood Adhesives: Preparation, Characterization, and Testing (pp. 86-110). CRC Press, Boca Raton, FL.

Wang, D., Sun, X.S., Yang, G., \& Wang, Y. (2009). Improved water resistance of soy protein adhesive at isoelectric point. Trans. ASABE, 52, 173-177.

Zhong, Z., \& Sun, X. (2001). Thermal and mechanical properties and water absorption of sodium dodecyl sulfate-modified soy protein (11S). J. Appl. Polymer Sci., 81, 166-175.

\section{Copyrights}

Copyright for this article is retained by the author(s), with first publication rights granted to the journal.

This is an open-access article distributed under the terms and conditions of the Creative Commons Attribution license (http://creativecommons.org/licenses/by/4.0/). 